J. Perinat. Med. $16(1988)$

\section{Herpes simplex virus infection in women with previous spontaneous abortion}

\author{
Marina Bujko1, Vojin Šulovic², Vera Živanovic, Rajko Dotlić1, Ivana Bardič1 \\ ${ }^{1}$ Institute of Microbiology and Immunology, ${ }^{2}$ Clinic of Gynecology and Obstetrics, \\ ${ }^{3}$ School of Medicine, University of Belgrade, Yugoslavia
}

\section{Introduction}

The first reports indicating that Herpes simplex virus (HSV) genital infection is a possible cause of spontaneous abortion were published by BONE AND LOFFREDO [1]. Intrauterine HSV infection caused such damage that further fetal development was not possible. The literature published after 1970 includes several other reports making the connection between HSV genital infection and spontaneous abortion. Ascending intrauterine infection was involved in most cases, though the possibility of transplacental transmission is not ruled out. This route is being increasingly associated with primary HSV infection, in which viremia occurs in the absence of antibodies $[5,6,7,10]$.

We have carried out a retrospective clinical investigation in 45 women in their first and second trimester of pregnancy aiming to show the role of genital HSV infection in the genesis of spontaneous abortions.

\section{Material and methods}

The retrospective clinical study included a group of 25 women, who had had at least one previous spontaneous abortion, and another 20 who had not and who served as controls. Their ages ranged between 20 and 38 years. The reasons for their previous abortions were unknown. There was no evidence of any another gynecologic problem. We planned to examine the evidence of latent HSV type 1 and type 2 infection in the 45 subjects and to find the incidence of asymptomatic cervical and vaginal HSV infection. There were no cases of primary HSV infection.
Latent HSV infection was diagnosed with the microneutralization test, using VERO cells and the laboratory strains of HSV type 1 and type 2 (ATCC VR 539 and ATCC VR 734). The plastic plates for microneutralization containing VERO cells, virus and sera, were incubated in an atmosphere of $5 \% \mathrm{CO}_{2}$ [8]. All 45 sera were examined, and the titer of anti HSV type 1 and HSV type 2 antibodies was determinated. The presence of latent HSV type 1 and type 2 infection was diagnosed on the basis of these findings [9].

Asymptomatic HSV vaginal and cervical shedding was diagnosed by indirect immunofluorescence and cytological-Papanicolau staining. The presence of HSV in cervical smears was diagnosed on the basis of multinucleated cells and changes in nuclear chromatin [2].

The indirect immunofluorescence test was performed using the Gardner method [3]. The swabs were immediately put into transport medium (Eagle Basal Medium) with $10 \%$ calf serum and penicillin. In the laboratory excess fluid was squeered from the swab, and all fluid was centrifuged. After centrifugation at $1600 \mathrm{rpm}$ for 10 minutes, two smears of about 10 to $15 \mathrm{~mm}$ were made from pellet on the clean microscopic slide, fixed in cold acetone and prepared for indirect immunofluorescent staining.

\section{Results}

The highest incidence of latent HSV type 2 infection occurred in the patients who had had a previous miscarriage $(64 \%)$. This difference between 
Table I. Latent Herpes simplex virus infection in women who had previously had spontaneous abortion (group B) and control group (C).

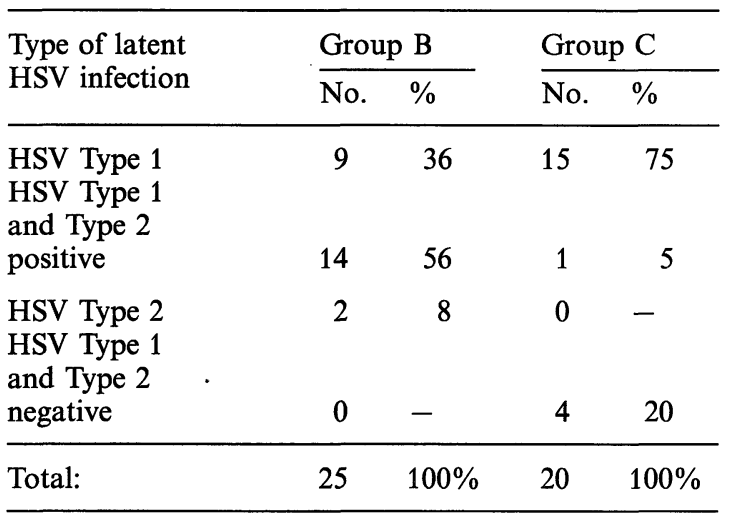

Group B and Group C is statistically significant $(X=16,82 ; p<0,01$, Table I).

The results presented in table II show no statistical difference $(X=0,84 ; p>0,05)$ between the incidence of individual types of vaginal infections in the two groups of pregnant women investigated. Positive HSV is found more frequently in Group B (12\% HSV type 1 and $20 \%$ HSV type 2 positive). In the control group, vaginal HSV type 1 and HSV type 2 infections were found in $5 \%$ and $10 \%$ cases, respectively.

A staticial analysis of incidence of cervical HSV type 1 infection showed no statistically significant difference between the findings in the group $B$ and group $C(X=0,3 ; P>0,05)$. The difference between the incidence of cervical HSV type 2 infection diagnosed in group $\mathrm{B}$ and that in group $\mathrm{C}$ approaches statistical significance $(P=0,08)$. Thus type of HSV infection was found in $16 \%$ of group B women investigated. No cases of cervical HSV type 2 infection were found in the control group (Table III).

The asymptomatic cervical HSV infection in Group B and the Control group was analysed in relation to both the positive and the negative findings. A comparison made between the incidence of positive and negative findings revealed a statistically significant difference $(X=5,39$;

Table II. Asymptomatic vaginal HSV infection in women who had previously had spontaneous abortion (group B) and in control group (C).

\begin{tabular}{|c|c|c|c|c|c|c|c|c|}
\hline \multirow[t]{4}{*}{ Group of pregnant women } & \multicolumn{8}{|c|}{$\mathrm{IF}^{*}$ findings } \\
\hline & \multicolumn{4}{|c|}{$\begin{array}{l}\text { Herpes simplex virus } \\
\text { Type } 1\end{array}$} & \multicolumn{4}{|c|}{$\begin{array}{l}\text { Herpes simplex virus } \\
\text { Type } 2\end{array}$} \\
\hline & \multicolumn{2}{|c|}{ Positive } & \multicolumn{2}{|c|}{ Negative } & \multicolumn{2}{|c|}{ Positive } & \multicolumn{2}{|c|}{ Negative } \\
\hline & No. & $\%$ & No. & $\%$ & No. & $\%$ & No. & $\%$ \\
\hline B & 3 & 12 & 22 & 88 & 5 & 20 & 20 & 80 \\
\hline $\mathrm{C}$ & 1 & 5 & 19 & 95 & 2 & 10 & 18 & 90 \\
\hline
\end{tabular}

$\mathrm{IF}^{*}=$ Immunofluorescence test

Table III. Asymptomatic cervical HSV infection in women who had previously had spontaneous abortion. Group (B) and and in control group (C).

\begin{tabular}{|c|c|c|c|c|c|c|c|c|}
\hline \multirow[t]{4}{*}{ Group of pregnant women } & \multicolumn{8}{|c|}{ IF* findings } \\
\hline & \multicolumn{4}{|c|}{$\begin{array}{l}\text { Herpes simplex virus } \\
\text { Type } 1\end{array}$} & \multicolumn{4}{|c|}{$\begin{array}{l}\text { Herpes simplex virus } \\
\text { Type } 2\end{array}$} \\
\hline & \multicolumn{2}{|c|}{ Positive } & \multicolumn{2}{|c|}{ Negative } & \multicolumn{2}{|c|}{ Positive } & \multicolumn{2}{|c|}{ Negative } \\
\hline & No. & $\%$ & No. & $\%$ & No. & $\%$ & No. & $\%$ \\
\hline B & 1 & 4 & 24 & 96 & 4 & 16 & 21 & 84 \\
\hline $\mathrm{C}$ & 1 & 5 & 19 & 95 & 0 & & 20 & 100 \\
\hline
\end{tabular}

$\mathrm{IF}^{*}=$ Immunofluorescence test 
Table IV. Asymptomatic cervical HSV infection in women who had previously had spontaneous abortion (group B) and in control group (C) - Cytologic findings.

\begin{tabular}{|c|c|c|c|c|c|c|c|}
\hline \multirow{3}{*}{$\begin{array}{l}\text { Group of } \\
\text { pregnant women }\end{array}$} & \multicolumn{7}{|c|}{ Cytologic Findings } \\
\hline & \multicolumn{2}{|c|}{ HSV positive } & \multicolumn{2}{|c|}{ HSV negative } & \multicolumn{2}{|c|}{ Colpitis } & \multirow[t]{2}{*}{ Total } \\
\hline & No. & $\%$ & No. & $\%$ & No. & $\%$ & \\
\hline B & 8 & 32 & 14 & 56 & 3 & 12 & 25 \\
\hline $\mathrm{C}$ & 1 & 5 & 17 & 85 & 2 & 10 & 20 \\
\hline
\end{tabular}

$\mathrm{p}<0,05)$. It can be concluded on the basis of these results that groups $\mathrm{B}$ and $\mathrm{C}$ differ significantly with regard to positive findings, since HSV cervical infection is more frequent in group B $(32 \%)$, Table IV).

\section{Discussion}

The generally accepted opinion is that $15 \%$ of all pregnancies end in spontaneous abortion. Despite the effort devoted to attempts to eliminate the causes of these abortions, this percentage has not been significantly reduced. The discovery of GREGG (1941), that the rubella virus has a teratogenic effect, drew attention to other microorganisms capable of damaging the embryo or fetus thus result in an spontaneous abortions prior to the 28th week of gestation [4]. Our investigation found the highest incidence of latent HSV type 2 infection $(64 \%)$ in the group of women who had had previous spontaneous abortions, whereas this type of infection was found in only $5 \%$ of pregnant women in the control group. This difference is statistically significant. The presence of this latent HSV infection is important, because it could become active following the physiological changes associated with pregnancy. This may occur even in the absence of clinical signs and symptoms.

Asymptomatic vaginal HSV type 1 and 2 infections were found in $12 \%$ and $20 \%$ of cases re-

\footnotetext{
Abstract

We have carried out a retrospective clinical investigation of 45 women in the first and second trimester of pregnancy aiming to demonstrate the role of genital HSV infection in the genesis of spontaneous abortion (miscarriage).

Latent HSV infection was diagnosed using the microneutralization test; asymptomatic HSV vaginal or cer-
}

spectively, in the group of women who had previously had spontaneous abortions. Such a finding is considerably more frequent than in the control group (5\% HSV type 1 positive and $10 \% \mathrm{HSV}$ type 2 positive).

The presence of cervical HSV infection was documented by cytological examination in $32 \%$ of the patients who had had spontaneous abortions, and only $5 \%$ of those in the central group. This difference was statistically significant.

The immunofluorescence test showed that HSV type 2 predominates since $16 \%$ HSV type 2 positive cervical swabs were found in the group who had had spontaneous abortions previously.

\section{Conclusion}

Our results indicate a statistically significant difference between the presence of latent HSV type 2 infection in women who have had spontaneous abortions and in those from control group. The highest incidence of this infection is found in women who have had spontaneous abortions, in whom the incidence of asymptomatic cervical HSV type 2 infection is also considerably higher. Our investigation clearly indicates a aetiological connection between HSV type 2 and spontaneous abortion.

vical shedding was diagnosed with indirect immunofluorescence and cytological-Papanicolau staining.

The results showed that the highest incidence ofl latent HSV type 2 infection $(64 \%)$ occurred in women who had one or more spontaneous abortions, whereas this type of infection was found in only $5 \%$ of pregnant women of the control group. The incidence of asymp- 
tomatic cervical HSV type 2 infection was also considerably higher in patients with a history of spontaneous abortions.
Our results indicate a possible aetiological connection between HSV and spontaneous abortion.

Keywords: Asymptomatic cervical HSV infection, Genital herpes, Latent HSV infection, Spontaneous arbortion.

\section{Zusammenfassung}

Herpes-Simplex-Infektionen bei Frauen mit vorangegangenen Spontanaborten

Retrospektiv wurden 45 Frauen im ersten und zweiten Schwangerschaftstrimenon untersucht, wobei Genitalinfektionen mit Herpes-Simplex-Virus (HSV) als ätiologischer Faktor für Spontanaborte interessierten.

Eine latente HSV-Infektion wurde über den Mikroneutralisationstest diagnostiziert. Mit der indirekten Immunfluoreszenz und Färbung nach Papanicolau wurden asymptomatische Besiedlungen von Vagina und Cervix mit HSV nachgewiesen.
Die höchste Inzidenz von latenten HSV-Typ 2-Infektionen (64\%) fand sich bei Frauen mit einem oder mehr vorangegangenen Spontanaborten. In der Kontrollgruppe betrug die Inzidenz 5\%. Asymptomatische cervicale Infektionen mit HSV-Typ 2 waren bei Patientinnen mit Spontanaborten in der Anamnese ebenfalls wesentlich häufiger.

Unsere Ergebnisse zeigen sehr deutlich einen möglichen ätiologischen Zusammenhang zwischen HSV-Typ 2 und Spontanabort.

Schlüsselwörter: asymptomatische cervicale HSV-Infektion, Herpes genitalis, latente HSV-Infektion, Spontanabort.

\section{Résumé}

Infection à herpes simplex virus chez les femmes ayant des antécédents de fausses-couches spontanées

Nous avons réalisé une étude clinique retrospective chez 45 femmes au cours du premier ou du deuxième trimestre de leur grossesse dans l'optique de montrer le rôle de l'infection génitale à HSV dans la genèse des fausses couches spontanées.

On a fait le diagnostic d'infection latente à HSV à l'aide du test de microneutralisation. Les pertes avec HSV Asymptomatiques vaginales ou cervicales ont été dia- gnostiquées par immunofluorescence indirecte et la coloration de Papanicolaou.

Les résultats obtenus montrent que l'incidence la plus élevée d'infections latentes à HSV de type $2(64 \%)$ se retrouve chez les femmes qui ont eu un avortement ou plus, alors que ce type d'infection n'est trouvé que chez $5 \%$ des femmes enceintes du groupe contrôle. Lincidence des infections cervicales asymptomatiques à HSV de type 2 est également plus élevée de façon considérable chez les patientes qui présentent dans leurs antécédents des avortements spontanés.

Mots-clés: Infection cervicale asymptomatique à HSV, herpes génital, infection latente à HSV, avortement spontané.

\section{References}

[1] BONE A, V LOFFredo: Avortement cause pr le virus de l'herpes type II. Isolement du virus a' partir de cultures de tissues zygotiques. Presse Med. 78 (1970) 103

[2] Coleman DV: Cytologic diagnosis of virus-infected cells in cervical smears. Value in gynecologic and obstetric practice. Diagn. Gynecol. Obstet. 4/4 (1982) 363

[3] GARDNER PS, J MCQuILLIN: Rapid virus diagnosis, Application of immunofluorescence. Butterworth \& Co., London 1980

[4] GREGG NM: Congenital cateract following German measles in the mother. Trans. Ophtal. Soc. Aus. 3 (1941) 34

[5] HaIN J, N Doshi, JH Harger: Ascending transcervical herpes simplex infection with intact fetal membranes. Obstet. Gynecol. 56 (1980) 106

[6] Komorous JM, CE Wheeler, RA Briggman, J CARO: Intrauterine herpes simplex infection. Arch. Dermatol. 113/7 (1977) 918

[7] LEDGER WJ: Premature rupture of the membranes and maternal-fetal infection. Clin. Obstet. Gynecol. 22 (1979) 329

[8] LeNETTE E., N SCHMiDT: Diagnostic procedures of viral and rickettsial infections. American Public Health Association, Washington 1979

[9] Nahmias JA, EW žJosey, MZ Naib, FC LuCE, A DuFfEY: Antibodies to herpesvirus hominis type $\mathbf{i}$ and 2 in humans; patients with genital herpetic infections. Am. J. Epidem. 91/6 (1970) 539

[10] REIKVAM TM, T RUD, V SKaNG: Intrauterine herpes simplex virus infection. Premature newborn with disseminated infection at delivery. Zentralbl. Gynakol. 103/23 (1981) 1473

Received August 17, 1987. Revised December 22, 1987. Accepted January 5, 1988.

Dr. Marina Bujko

Tadeuša Košćuškog 78

11000 Beograd, Yugoslavia 